\title{
PENILAIAN KINERJA DOSEN BIDANG KOMPETENSI BELAJAR MENGAJAR
}

\author{
Muhammad Sapruwan'), Sanjaya Endra Setyawan') \\ Universitas Pelita Bangsa, Jl. Inpeksi Kalimalang Tegal Danas Arah Delta Mas Cikarang \\ Pusat Kab. Bekasi 17530, Jawa Barat \\ E-mail:msapruwan@yahoo.com
}

\author{
Akuntansi Bisnis dan \\ Manajemen (ABM), \\ Volume 27 \\ Nomor 1 \\ Halaman 41- 52 \\ Bulan April, Tahun 2020 \\ ISSN 0854-4190 \\ E-ISSN 2685-3965
}

The purpose of this study is to know how to assess the performance of lecturers in teaching and learning competence, and how is the application of the weighted product method?.The criteria used are Time, Neatness, Communication, Lecture Process, Mastery of Material, Learning Evaluation. Through samples five lecturers by using the Weighted Product method, the weight is obtained with the initials of the lecturer ASR., while lecturer which has the lowest weight the initials ACP.The implications of this research study are on the basis of these weights can be used as a foundation in decision making Pelita Bangsa University's management policy actions. Lecturers who get good grades should get appreciation, while lecturers who score less will be trained. What distinguishes this research study With other research is Lecturer performance evaluation is carried out by students And followed by the weighted product method which has not been widely used in universities.

Keywords: Lecturer Performance Assessment; Learning Competencies; and Weighted Product

Informasi Artikel

Tanggal Masuk:

04 Februari 2020

Tanggal Revisi:

20 Februari 2020

Tanggal Diterima:

10 April 2020

\begin{abstract}
Abstrak
Tujuan penelitian ini adalah untuk mengetahui bagaimana penilaian kinerja dosen bidang kompetensi belajar mengajar, dan bagaimana penerapan metode weighted product ?. Kriteria yang digunakan adalah Waktu, Kerapihan, Komunikasi, Proses Perkuliahan, Penguasaan Materi, Evaluasi Belajar. Melalui sampel data 5 (lima) orang dosen dengan menggunakan metode Weighted Product dan tool- excell, diperoleh bobot yang terbaik dengan inisial dosen ASR., sedangkan dosen yang memiliki bobot terendah berinisial ACP. Implikasi kajian penelitian ini adalah atas dasar bobot tersebut dapat dijadikan landasan dalam pengambilan keputusan tindakan kebijakan Manajemen Universitas Pelita Bangsa. Dosen yang mendapatkan peringkat Bagus sebaiknya mendapatkan apresiasi, sedangkan dosen yang nilai kurang akan dilakukan pembinaan. Yang membedakan kajian penelitian ini dengan penelitian lainnya adalah penilaian kinerja dosen dilakukan oleh mahasiswa dan dilanjutkan dengan metode weighted product yang belum banyak digunakan di Perguruan tinggi.
\end{abstract}

Kata Kunci: Penilaian Kinerja Dosen; Kompetensi Pembelajaran; dan Weighted Product 


\section{PENDAHULUAN}

Universitas Pelita Bangsa (UPB) merupakan perguruan tinggi baru hasil perubahan bentuk dari penggabungan antara Sekolah Tinggi Ilmu Ekonomi (STIE) dan Sekolah Tinggi Teknik (STT) sesuai dengan Surat Keputusan Menteri Pendidikan Nasional Republik Indonesia Nomor: 664/KPTI/I/2019 tanggal 2 Agustus 2019. UPB berdiri pada hamparan lahan seluas $11.603 \mathrm{~m}^{2}$ yang beralamatkan di Jalan Inpeksi Kalimalang Tegal Danas Arah Deltamas, Cikarang Pusat - Kabupaten Bekasi. Universitas Pelita Bangsa berdiri sebagai wujud impian dari pendiri Yayasan Pelita Bangsa, yaitu Bapak Ir. Mardiyana, MM. Beliau ingin menciptakan lulusan yang bermoral tinggi, berjiwa entrepreneur, gigih, memiliki kompetensi intelektual, dan menjadi harapan bangsa.

Dosen adalah pendidik profesional dan ilmuwan dengan tugas utama mentransformasikan, mengembangkan, dan menyebarluaskan ilmu pengetahuan, teknologi, dan seni melalui pendidikan, penelitian, dan pengabdian kepada masyarakat. Dosen tetap adalah dosen yang bekerja penuh waktu yang berstatus sebagai tenaga pendidik tetap pada satuan pendidikan tinggi tertentu. (PP No. 37, 2009). Berdasarkan Pangkalan Data Pendidikan Tinggi Kementrian Riset, Tekhnologi, Dan Pendidikan Tinggi, pada tahun 2019. Saat ini Universitas Pelita Bangsa tercatat memiliki dosen program studi manajemen sekitar 140 orang. Jumlah yang menurut ukuran peneliti cukup banyak untuk universitas yang masih baru berdiri. Namun demikian setelah diamati lebih lanjut banyak yang tidak linier dibidangnya. Berkaitan dengan hal tersebut maka kinerjanya perlu diteliti lebih lanjut. Pernyataan dari Sari dan Susilo (2018) menjelaskan kinerja adalah hasil atau tingkat keberhasilan seseorang secara keseluruhan selama periode tertentu dalam melaksanakan tugas dibandingkan dengan berbagai kemungkinan, seperti standar hasil kerja, target atau sasaran atau kriteria yang telah ditentukan terlebih dahulu yang telah disepakati bersama. Anggraeni (2011) menyatakan bahwa kinerja kinerja pegawai adalah hasil yang dicapai dari kemampuan dan motivasi yang dimiliki oleh pegawai.

Kualifikasi dosen bukan hanya ijazah dengan gelar megister (S2) atau doktor (S3) saja, akan tetapi mampu mentransformasikan ilmunya dengan baik, mampu memunculkan kreatifitasnya dalam membuat suasana belajar mengajar lebih aktif dan interaktif. Hal ini bisa dilakukan bilamana kompetensi seorang dosen dibidang belajar mengajar telah teruji. Selain itu, berdasarkan hasil pengamatan peneliti, program studi manajemen belum memiliki sistem penilaian kinerja dosen, dan evaluasi kinerja dosen belum pernah dilakukan. Dengan demikian hal mendesak yang harus segera dilakukan adalah evaluasi dosen untuk mengetahui dosen yang berkualitas. Berdasarkan uraian latar belakang diatas, maka penelitian ini bertujuan untuk memberikan bantuan bagaimana melakukan penilaian kinerja dosen bidang kompetensi belajar mengajar guna mengetahui kualitas dosen program studi manajemen Unversitas Pelita Bangsa.

\section{KAJIAN PUSTAKA}

Menurut Ananta dan Winiarti (2013) Penilaian kinerja pegawai merupakan proses penilaian yang dilakukanperusahaan untuk menghasilkan pegawai yang berkualitas dan berdedikasi tinggi. Kegiatan ini dapat memperbaiki keputusan- 
keputusan personalia dan memberikan umpan balik kepada para karyawan atas pelaksanaan kerja mereka. Sedangkan menurut Hartanto (2019) Performance Appraisal atau penilaian kinerja merupakan suatu sistem yang digunakan untuk meninjau dan mengevaluasi performa kerja individu atau tim. Tujuan akhir dari performance appraisal adalah meningkatkan kinerja dari individu, tim dan keseluruhan bagian yang terlibat dalam suatu perusahaan. Jadi penilaian kinerja adalah penting dalam perusahaan karena dapat memberikan motivasi bagi karyawan untuk berkembang lebih baik lagi.

Selanjutnya menurut Taufiq (2015) bahwa kriteria penilaian kinerja yang digunakan dalam proses penilaian bidang belajar mengajar sebanyak 6 kriteria, yakni waktu, kerapihan, komunikasi, proses perkuliahan, penguasaan pateri dan evaluasi belajar. Waktu merupakan salah satu kriteria yang berhubungan dengan waktu yang dilakukan pada saat pelaksanaan proses belajar mengajar adapun yang dinilai dalam Waktu adalah Kehadiran dosen pada saat memulai dan mengakhiri perkuliahan, kehadiran dosen dengan jadwal, pelaksanaan ujian. Kerapihan merupakan kriteria yang kedua yang dinilai dalam proses belajar mengajar di fakultas teknik, adapun yang dinilai dalam kerapihan adalah kesopanan pakaian, kerapihan pakaian, kebersihan dan keserasihan pakaian. Komunikasi kriteria yang ketiga dan yang dinilai dalam komunikasi adalah kejelasan kalimat, sopan santun kalimat dan tata bahasa. Proses Perkuliahan kriteria yang keempat adapun yang dinilai dalam proses perkuliahan adalah bagaimana dosen menjelaskan SAP diawal perkuliahan, menggunakan infokus dalam proses belajar, menciptakan suasana kondusif dan menggunakan metode yang tepat. Penguasaan Materi merupakan kriteria yang kelima adapaun yang dinilai dalam penguasaan materia adalah tingkat penyampaian materi, ada hubungan antar pertemuan, cara menjawab pertanyaan dari mahasiswa. Evaluasi belajar merupakan kriteria yang terakhir adapun yang dinilai dalam evaluasi adalah kesesuaian materi dengan soal, presentasi penilaian dan bentuk soal.

UU Nomor 14 Tahun 2005 tentang Guru dan Dosen, dosen dinyatakan sebagai pendidik profesional dan ilmuwan dengan tugas utama mentransformasikan, mengembangkan, dan menyebarluaskan ilmu pengetahuan, teknologi, dan seni melalui pendidikan, penelitian, dan pengabdian kepada masyarakat (Bab 1 Pasal 1 ayat 2). Sementara itu, profesional dinyatakan sebagai pekerjaan atau kegiatan yang dilakukan oleh seseorang dan menjadi sumber penghasilan kehidupan yang memerlukan keahlian, kemahiran, atau kecakapan yang memenuhi standar mutu atau norma tertentu serta memerlukan pendidikan profesi. Dosen adalah salah satu komponen esensial dalam suatu sistem pendidikan di perguruan tinggi. Peran, tugas, dan tanggungjawab dosen sangat penting dalam mewujudkan tujuan pendidikan nasional. Untuk melaksanakan fungsi, peran, dan kedudukan yang sangat strategis tersebut, diperlukan dosen yang profesional.

Kompetensi tenaga pendidik, khususnya dosen, diartikan sebagai seperangkat pengetahuan, keterampilan dan perilaku yang harus dimiliki, dihayati, dikuasai dan diwujudkan oleh dosen dalam melaksanakan tugas profesionalnya. Kompetensi tersebut meliputi kompetensi pedagogik, kompetensi kepribadian, kompetensi sosial dan kompetensi profesional. Sedangkan pernyataan dari Dessler (2011:435) bahwa Competencies: Demonstrable knowledge, skills, or behavior, that enable performance (Kompetensi: pengetahuan, keterampilan, atau perilaku, kinerja). Menurut Permanasari, (2014) Kompetensi sebagai seperangkat tindakan intelegensi penuh 
tanggung jawab yang harus dimiliki seseorang sebagai syarat untuk dianggap mampu melaksanakan tugas-tugas dalam bidang pekerjaan tertentu Kompetensi dapat dikelompokkan ke dalam tiga bagian, yaitu: Knowledge (ilmu pengetahuan, Skill (keahlian, keterampilan), Kualitas personal/ attitude (sikap). Knowledge yakni: Akumulasi pengetahuan yang diperlukan untuk melaksanakan tugas yang diberikan, termasuk dalam pengetahuan ini adalah learning technology. Skill yakni: keahlian, kemahiran, kemampuan, serta keteramplian dalam mengaplikasikan ilmu pengetahuan, teknik, metode, dan prinsip yang diperoleh melalui pendidikan, pelatihan, observasi, dan praktek lapangan/ magang. Attitude yakni: sikap/ tingkah laku yang tepat yang senantiasa ada di dalam diri sebagai dasar melakukan tindakan tertentu. Dengan demikian dapat dirumuskan kompetensi adalah standar kualitas (keunggulan yang kompetitif) yang dimiliki oleh seseorang berupa pengetahuan, keterampilan dan sikap kerja dalam menjalankan tugas dan tanggung jawab jabatannya untuk mencapai tujuan organisasi. Berkaitan dengan hal tersebut maka sangat penting sekali dalam memperhatikan kompetensi. Hal ini senada dengan pernyataan dari Yuningsih dan Ardianti ( 2019) Kompetensi merupakan kekuatan melakukan suatu pekerjaan yang didasari kemampuan yang relevan yang didorong oleh sikap dalam melaksanakan pekerjaan sesuai standar kerja yang ditetapkan.

Konsep Pembelajaran, menurut Undang-Undang No. 20 Tahun 2003 tentang Sistem Pendidikan Nasional, pendidikan adalah usaha sadar dan terencana untuk mewujudkan suasana belajar dan proses pembelajaran agar peserta didik secara aktif mengembangkan potensi dirinya untuk memiliki kekuatan spiritual keagamaan, pengendalian diri, kepribadian, kecerdasan, akhlak mulia, serta keterampilan yang diperlukan dirinya, masyarakat, bangsa dan negara. Pengajaran adalah merupakan suatu proses interaksi peserta didik dengan pendidik dan sumber belajar pada suatu lingkungan belajar. Penilaian untuk pengajaran adalah berapa banyak dosen tersebut mengampu mata kuliah pada satu semester.

Dari kajian pustaka diatas, maka dapat disimpulkan penilaian kinerja dosen bidang kompetensi belajar mengajar adalah proses mengevaluasi dosen dalam mengampu mata kuliah tertentu dengan menggunakan kriteria ukur bidang pembelajaran seperti waktu, kerapihan, komunikasi, proses perkuliahan, penguasaan materi dan evaluasi belajar yang dilakukan oleh peserta didik (mahasiswa) untuk memperoleh mengetahui kemampuan pengetahuan, keahlian, dan sikap pendidik (dosen) sebagai informasi manajemen dalam mengambil keputusan terhadap dosen yang bersangkutan.

\section{METODE PENELITIAN}

Berdasarkan uraian di atas, maka peneliti membuat kerangka berpikir dalam penelitian ini sebagai berikut: 


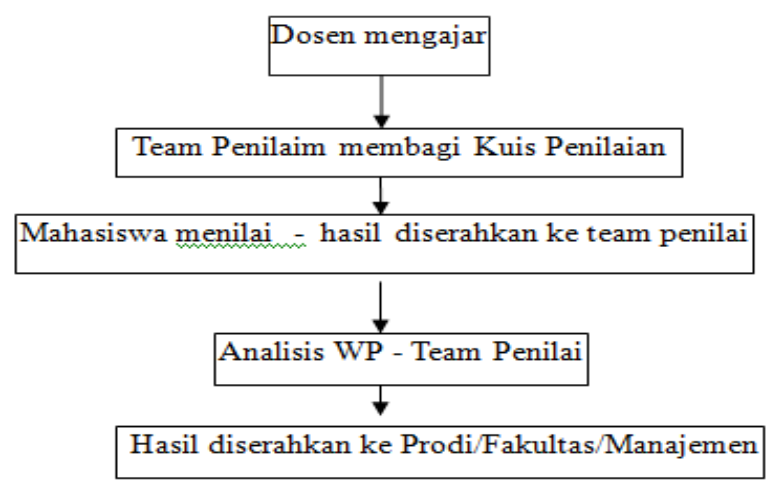

Gambar 1. Kerangka Penilaian Kinerja Dosen

Kerangka penilaian kinerja dosen dalam bidang kompetensi belajar mengajar yang dilakukan oleh mahasiswa, selanjutnya dievaluasi oleh team penilai fakultas masing-masing untuk dianalisis dengan metode weighted product (WP). Hasil penilaian kinerja dosen diserahkan ke Kaprodi Fakultas masing-masing/Manajemen UPB untuk diambil tindakan/kebijakan terhadap dosen yang dinilai tersebut. Bilamana terdapat dosen yang nilainya dibawah standar maka pihak fakultas dapat memanggil dosen yang bersangkutan untuk diajak sharing.

Evaluasi dan Standart Penilaian, Cara melakukan evaluasi proses belajar mengajar dosen yang dilakukan oleh mahasiswa terdiri dari beberapa langkah, langkah-langkah tersebut adalah: (1) Mahasiswa dibagikan form penilaian kinerja dosen. (2) Mahasiswa melakukan penilaian kinerja dosen yang terdiri dari 6 kriteria dengan memberikan angka penilaian 0 - 100 (3) Form dikumpulkan selanjutnya dilakukan penjumlahan oleh team penilai (4) Setelah dirata-rata nilai dosen, selanjutnya dianalisis dengan WP.

Tabel 1. Form Penilaian Dosen

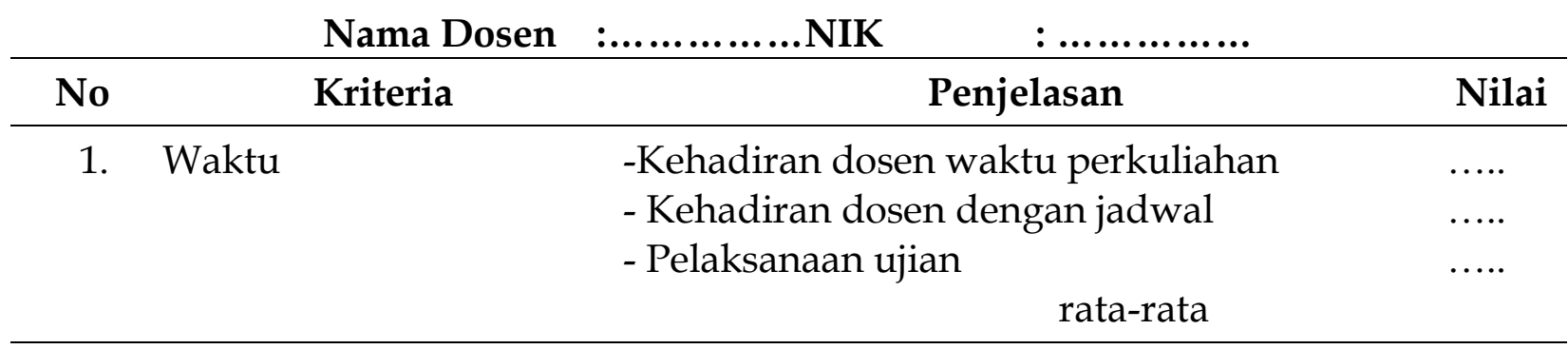

2. Kerapihan - Kesopanan pakaian

- Kerapihan pakaian

- Kebersihan

- Keserasihan pakaian

rata-rata

3. Komunikasi - Kejelasan kalimat

- Sopan santun kalimat

- Tata bahasa

rata-rata

4. Proses Perkuliahan - Menjelaskan SAP

- Menggunakan Infokus 
- Menciptakan suasana kondusif

- Menggunakan metode yang tepat

$\cdots \cdots$

rata-rata

\begin{tabular}{|c|c|c|c|}
\hline 5. & Penguasaan Materi & $\begin{array}{l}\text { - Tingkat penyampaian materi } \\
\text { - Ada hubungan antar pertemuan } \\
\text { rata-rata }\end{array}$ & $\begin{array}{l}\ldots \ldots \\
\ldots \ldots\end{array}$ \\
\hline 6. & Evaluasi Belajar & $\begin{array}{l}\text { - Kesesuaian soal dengan materi } \\
\text { - Presentasi penilaian } \\
\text { - Bentuk soal }\end{array}$ & $\begin{array}{l}\cdots \cdots \\
\cdots \\
\cdots \cdots\end{array}$ \\
\hline
\end{tabular}

Analisis Weighted Product merupakan sebuah metode didalam penentuan sebuah keputusan dengan cara perkalian untuk menghubungkan rating atribut, dimana setiap rating atribut harus dipangkatkan dulu dengan bobot atribut yang bersangkutan. Nofriansyah (2015:47-48). Adapun deskriptif perhitungan Weighted Product yaitu: (1) Melakukan penginputan data (data disini adalah data dosen, data nilai, dan bobot untuk kompetensi bidang belajar mengajar (2) Menghitung perbaikan bobot (3) Menghitung vektor s (4) Menghitung vektor v. Dari hasil perhitungan nilai V diatas, menunjukan nilai bobot seorang dosen. Untuk membantu peniliti dalam proses perhitungan weighted product digunakan aplikasi program excell. Berikut adalah flowchart Weighted Product :

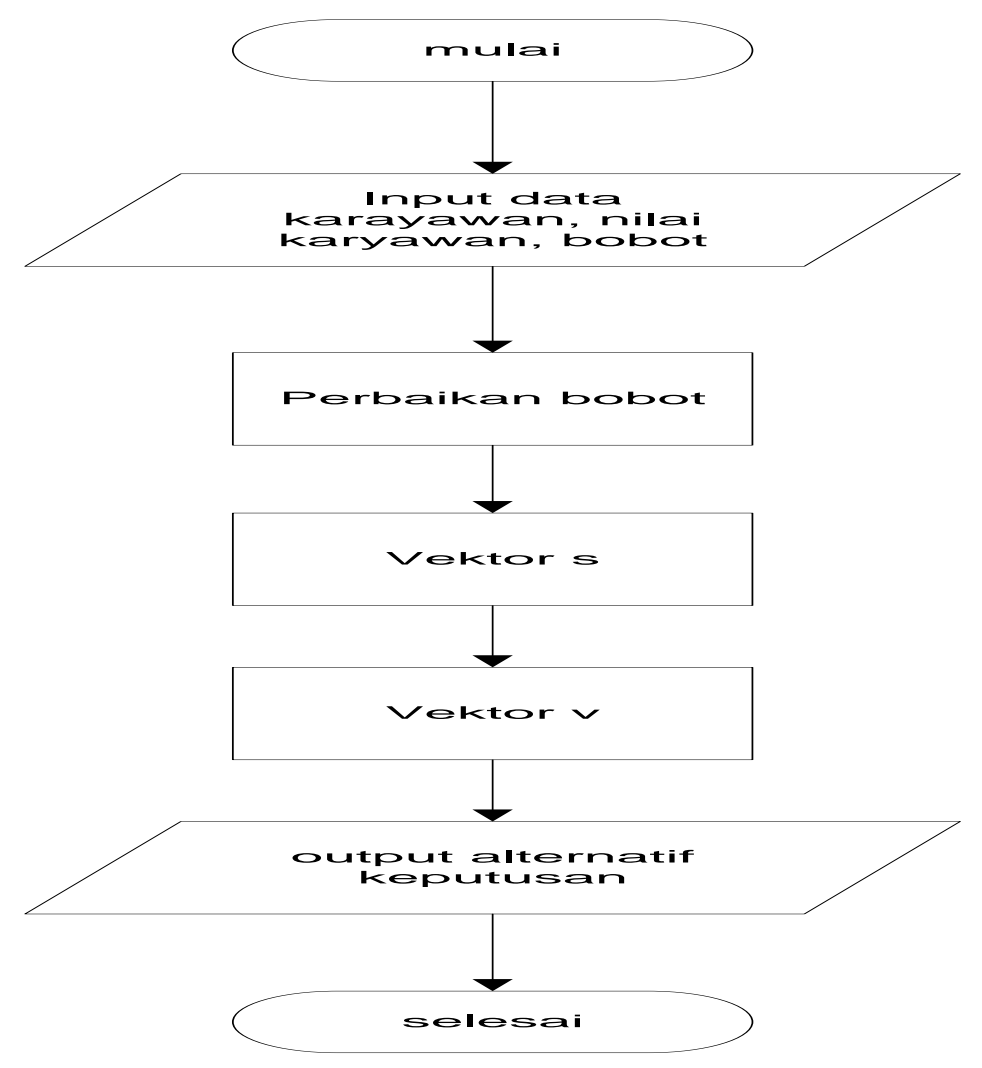

Gambar 2: Flowchart Weighted Product 
Langkah-langkah dalam perhitungan WP adalah sebagai berikut: (1) Mengalikan seluruh atribut bagi seluruh alternatif dengan bobot sebagai pangkat positif bagi atribut biaya (2) Hasil perkalian dijumlahkan untuk menghasilkan nilai pada setiap alternatif (3) Membagi Nilai V bagi setiap alternatif dengan nilai pada setiap alternatif, dan (4) Ditemukan urutan alternatif terbaik yang akan menjadi keputusan. Preferensi untuk alternatif Ai diberikan sebagai berikut:

$$
\begin{aligned}
& \mathrm{w}_{\mathrm{J}}=\frac{w j}{\sum w_{j}} \\
& \mathrm{~s}_{\mathrm{i}}=\prod_{j=1}^{n} X_{i j} \mathrm{w}_{\mathrm{j}}
\end{aligned}
$$

Dimana:

$\mathrm{S} \quad$ : menyatakan preferensi alternative dianalogikan sebagai vector S

$\mathrm{X} \quad$ : menyatakan nilai kriteria

W : menyatakan nilai bobot kriteria

i : menyatakan alternatif

J : : menyatakan kriteria

$\mathrm{N} \quad$ : menyatakan banyaknya kriteria

Wj : menyatakan pangkat bernilai positif untuk atribut keuntungan dan negatif bernilai negatif untuk atribut biaya

Preferensi untuk alternatif Vi diberikan sebagai berikut :

$$
\mathrm{V}_{\mathrm{i}}=\frac{\prod_{j=1}^{n} X_{i j} \mathrm{wj}}{\prod_{J=1}^{n}\left(X_{j}\right) \mathrm{wj}}
$$

Dimana:

$\mathrm{V} \quad$ : menyatakan preferensi alternative dianalogikan sebagai vector $\mathrm{V}$

$\mathrm{X} \quad$ : menyatakan nilai kriteria

W : menyatakan nilai bobot kriteria

I : menyatakan alternatif

J : : menyatakan kriteria

$\mathrm{N} \quad$ : menyatakan banyaknya kriteria

\section{HASIL DAN PEMBAHASAN}

Penerapan metode Weighted Product harus dilengkapi dengan data-data seperti: (1) Data Dosen, (2) Data Bobot dan Penilaian (3) Data Hasil Penilaian. Untuk menjaga kerahasiaan data dosen, maka nama sampel dosen yang diteliti disajikan dalam bentuk inisial. Penggunaan data ini hanya dimaksudkan untuk mempermudah pemahaman metode Weighted Product dalam penerapannya.

\section{Data Dosen}

Adapun data dari dosen adalah sebagai berikut:

Tabel 2. Data Dosen

\begin{tabular}{ccc}
\hline No. & NIK & Nama Dosen \\
\hline 1 & $21.0819 . \times x x$ & A C P \\
2 & $21.0819 . \times x x$ & A I S \\
3 & $21.0819 . \times x x$ & A Y \\
4 & $21.0819 . \times x x$ & A S R \\
5 & $21.0819 . \times x x$ & A M T \\
\hline
\end{tabular}


Data Bobot dan Penilaian (dari Kaprodi)

Tabel 3. Bobot Penilaian

\begin{tabular}{|c|c|c|}
\hline Kode & Kompetensi & Bobot \\
\hline $\mathrm{c} 1$ & Waktu & $15 \%$ \\
\hline c2 & Kerapian & $10 \%$ \\
\hline c3 & Komunikasi & $15 \%$ \\
\hline$c 4$ & Proses Perkuliahan & $25 \%$ \\
\hline c5 & Penguasaan Materi & $25 \%$ \\
\hline c6 & Evaluasi Belajar & $10 \%$ \\
\hline
\end{tabular}

\section{Data Rekapitulasi Penilaian Dosen (dari Mahasiswa)}

\section{Tabel 4. Rekapitulasi Penilaian Dosen}

\begin{tabular}{rllllllll}
\hline No & NIK & Nama Dosen & c1 & c2 & c3 & c4 & c5 & c6 \\
\hline 1 & $21.0819 . \times x x$ & A C P & 70 & 85 & 60 & 80 & 80 & 70 \\
2 & $21.0819 . x x x$ & A I S & 60 & 60 & 70 & 90 & 90 & 75 \\
3 & $21.0819 . \times x x$ & A Y & 85 & 85 & 85 & 80 & 80 & 75 \\
4 & $21.0819 . x \times x$ & A S R & 85 & 85 & 80 & 90 & 90 & 75 \\
5 & $21.0819 . x x x$ & A M T & 80 & 80 & 85 & 85 & 80 & 80 \\
\hline
\end{tabular}

\section{Pengolahan Data}

Berikut Proses perhitungan dengan menggunakan metode Weighted Product: (a) Melakukan penginputan data (nama dosen, bobot kompetensi, nilai dosen) (b) Menghitung perbaikan bobot. (c) Menghitung vektor s (d) Menghitung vektor v

\section{Tahap 1: Menginput Data Nilai Dosen}

Penillaian setiap kriteria, pada tahap ini nantinya nilai diinput oleh bagian team penilai (data Tabel 4).

\section{Tahap II: Perbaikan bobot}

Dari bobot preferensi sebelumnya yaitu $W=(15 \%, 10 \%, 15 \%, 25 \%, 25 \%, 15 \%$, Perbaikan bobot menjadi:

$$
\begin{aligned}
\mathbf{w} 1 & =\frac{0.15}{\mathbf{0 . 1 5}+0.1+0.15+0.25+0.25+0.1}=0.15 \\
\mathbf{w} 2 & =\frac{0.1}{\mathbf{0 . 1 5}+0.1+0.15+0.25+0.25+0.1}=0.10 \\
\mathbf{w} 3 & =\frac{0.15}{\mathbf{0 . 1 5}+0.1+0.15+0.25+0.25+0.1}=0.15 \\
\mathbf{w} 4 & =\frac{0.25}{\mathbf{0 . 1 5}+0.1+0.15+0.25+0.25+0.1}=0.25 \\
\text { w5 } & =\frac{0.25}{\mathbf{0 . 1 5}+0.1+0.15+0.25+0.25+0.1}=0.25 \\
\text { w6 } & =\frac{0.1}{\mathbf{0 . 1 5}+0.1+0.15+0.25+0.25+0.1}=0.10
\end{aligned}
$$


Tahap III: Menentukan Nilai Vektor S

Tabel 5. Nilai Vektor $S$

\begin{tabular}{llcllllllr}
\hline No & NIK & Nama Dosen & c1 & c2 & c3 & c4 & c5 & c6 & Vector s \\
\hline 1 & 21.0819.xxx & A C P & 70 & 85 & 60 & 80 & 80 & 70 & 74.56 \\
2 & 21.0819.xxx & A I S & 60 & 60 & 70 & 90 & 90 & 75 & 76.90 \\
3 & 21.0819.xxx & A Y & 85 & 85 & 85 & 80 & 80 & 75 & 81.44 \\
4 & $21.0819 . \times x x$ & A S R & 85 & 85 & 80 & 90 & 90 & 75 & 85.59 \\
5 & $21.0819 . \times x x$ & A M T & 80 & 80 & 85 & 85 & 80 & 80 & 81.96 \\
\hline
\end{tabular}

Perhitungan Manual :

$\boldsymbol{S 1}=\left(\mathbf{7 0}^{\mathbf{0}, 15}\right)\left(\mathbf{8 5}^{\mathbf{0}, 10}\right)\left(\mathbf{6 0}^{\mathbf{0}, 15}\right)\left(\mathbf{8 0}^{\mathbf{0}, 25}\right)\left(\mathbf{8 0}^{\mathbf{0}, 25}\right)\left(\mathbf{7 0}^{\mathbf{0}, 10}\right)=74.56$
$\boldsymbol{S} 2=\left(\mathbf{6 0}^{\mathbf{0}, 15}\right)\left(\mathbf{6 0}^{\mathbf{0}, 10}\right)\left(\mathbf{7 0}^{\mathbf{0}, 15}\right)\left(\mathbf{9 0}^{\mathbf{0}, 25}\right)\left(\mathbf{9 0}^{\mathbf{0}, 25}\right)\left(\mathbf{7 5}^{\mathbf{0}, 10}\right)=76.90$
$\boldsymbol{S} 3=\left(\mathbf{8 5}^{\mathbf{0}, 15}\right)\left(\mathbf{8 5}^{\mathbf{0}, 10}\right)\left(\mathbf{8 5}^{\mathbf{0}, 15}\right)\left(\mathbf{8 0}^{\mathbf{0}, 25}\right)\left(\mathbf{8 0}^{\mathbf{0}, 25}\right)\left(\mathbf{7 5}^{\mathbf{0}, 10}\right)=81.44$
$\boldsymbol{S 4}=\left(\mathbf{8 5}^{\mathbf{0}, 15}\right)\left(\mathbf{8 5}^{\mathbf{0}, 10}\right)\left(\mathbf{8 0}^{\mathbf{0}, 15}\right)\left(\mathbf{9 0}^{\mathbf{0}, 25}\right)\left(\mathbf{9 0}^{\mathbf{0}, 25}\right)\left(\mathbf{7 5}^{\mathbf{0}, 10}\right)=85.59$
$\boldsymbol{S} 5=\left(\mathbf{8 0}^{\mathbf{0}, 15}\right)\left(\mathbf{8 0}^{\mathbf{0}, 10}\right)\left(\mathbf{8 5}^{\mathbf{0}, 15}\right)\left(\mathbf{8 5}^{\mathbf{0}, 25}\right)\left(\mathbf{8 0}^{\mathbf{0}, 25}\right)\left(\mathbf{8 0}^{\mathbf{0}, 10}\right)=81.96$

Tahap IV: Menghitung Preferensi (Vi)

Tabel 6: Nilai Vektor V

\begin{tabular}{llcc}
\hline No & NIK & Nama Dosen & Vector $\mathbf{~}$ \\
\hline 1 & 21.0819.xxx & A C P & 0.186180504 \\
2 & 21.0819.xxx & A I S & 0.192034835 \\
3 & 21.0819.xxx & A Y & 0.203361533 \\
4 & 21.0819.xxx & A S R & 0.213744884 \\
5 & 21.0819.xxx & A M T & 0.204678243 \\
\hline
\end{tabular}

Perhitungan Manual :

$$
\begin{aligned}
\mathbf{V} 1 & =\frac{\mathbf{7 4 . 5 6}}{\mathbf{7 4 . 5 6 + 7 6 . 9 0 + 8 1 . 4 4 + 8 5 . 5 9 + 8 1 . 9 6}}=0.186180504 \\
\mathbf{V} 2 & =\frac{\mathbf{7 6 . 9 0}}{\mathbf{7 4 . 5 6 + 7 6 . 9 0 + 8 1 . 4 4 + 8 5 . 5 9 + 8 1 . 9 6}}=0.192034835 \\
\mathbf{V} 3 & =\frac{\mathbf{8 1 . 4 4}}{\mathbf{7 4 . 5 6 + 7 6 . 9 0 + 8 1 . 4 4 + 8 5 . 5 9 + 8 1 . 9 6}}=0.203361533 \\
\mathbf{V} 4 & =\frac{\mathbf{8 5 . 5 9}}{\mathbf{7 4 . 5 6 + 7 6 . 9 0 + 8 1 . 4 4 + 8 5 . 5 9 + 8 1 . 9 6}}=0.213744884 \\
\mathbf{V} 5 & =\frac{\mathbf{8 1 . 9 6}}{\mathbf{7 4 . 5 6}+\mathbf{7 6 . 9 0 + 8 1 . 4 4 + 8 5 . 5 9 + 8 1 . 9 6}}=0.204678243
\end{aligned}
$$

Penilaian kinerja dosen semestinya harus dilakukan, dosen yang mendapatkan peringkat Bagus sebaiknya mendapatkan apresiasi, sedangkan dosen yang nilainya Cukup maka akan dilakukan komunikasi/sharing dengan dosen yang bersangkutan, sedangkan dosen yang nilai kurang akan dilakukan pembinaan. Hasil penelitian Taufiq R (2015) menyatakan bahwa permasalahan yang dikaji adalah adanya hasil kinerja dosen masih belum terukur. Selanjutnya dengan menggunakan 6 kriteria, yakni waktu, kerapihan, komunikasi, proses perkuliahan, penguasaan materi dan evaluasi belajar dibuat form evaluasi. Atas dasar kriteria tersebut hasil kinerja dosen dari proses belajar mengajar dapat diketahui bagus, cukup dan kurang. Kajian ini sangat 
cocok diterapkan di Universitas Pelita Bangsa, karena manajemen dapat mengetahui bagaimana kompetensi asset dosen yang dimilikinya. Penilaian kinerja menunjukan juga adanya perhatian dari Manajemen Universitas Pelita Bangsa terhadap dosen, sehingga mendorong dosen semangat untuk bekerja. Hal ini sesuai dengan pernyataan dari Siregar (2018) bahwa penilaian kinerja adalah proses mengevaluasi seberapa baik karyawan dalam melakukan pekerjaan mereka jika dibandingkan dengan seperangkat standar, kemudian mengomunikasikan informasi tersebut kepada karyawan Proses penilaian kinerja harus dilakukan dengan jujur, objektif, serta ada tindak lanjutnya. Sayangnya hasil nilai bagus, cukup dan kurang bagi dosen. Berdasarkan kajian penelitian tersebut, maka untuk memperoleh kaeakuratan dalam penilaian kinerja dosen, peneliti lanjutkan dengan menggunakan bobot penilaian, serta tahapan langkah-langkah teknis yang harus dilakukan.

Persiapan penilaian: (a) Kaprodi membentuk tim penilai kinerja dosen (jumlahnya disesuaikan dengan kebutuhan banyaknya dosen yang dimiliki, dan target berapa hari diselesaikan, (b) Kaprodi memberi data-data dosen yang akan dinilai kepada tim penilai (c) Tim penilai menyiapkan lembar kuisioner (d) Tim penilai dibagi menjadi beberapa kelompok untuk melakukan aktivitas pengumpulan penilaian dosen dari sampel kelas yang telah ditentukan. Pelaksanaan penilaian: (a) Mahasiswa dibagikan kuis form penilaian kinerja dosen (b) Mahasiswa melakukan penilaian kinerja dosen, dengan range angka penilaian 0-100 secara obyektif, dan tidak boleh ada pengaruh dari pihak manapun (c). Form penilaian kinerja dosen yang sudah terisi, dikumpulkan selanjutnya dilakukan penjumlahan oleh team penilai (d). Setelah diperoleh rata-rata penilaian masing-masing dosen, dapat dilakukan rekapitulasi dengan bantuan aplikasi program excell (e). Selanjutnya untuk memperoleh dosen yang kualified dibidang kompetensi belajar mengajar, maka dianalisis melalui perhitungan weighted product. Data-data yang diperlukan dalam kajian penelitian ini adalah sebagai berikut: (a) Data dosen, (b) Data kelas, (c) Form Penilaian Mahasiswa yang telah diisi, (d) Bobot Penilaian, dan (e) Rekapitulasi Penilaian Mahasiswa.

Hasil kajian peneliti adalah bobot yang terbaik adalah Sdr. A S R sebesar 0.213744884., sedangkan yang memiliki bobot terendah adalah Sdr. A C P sebesar 0.186180504. Atas dasar bobot tersebut dapat dijadikan landasan dalam pengambilan keputusan tindakan kebijakan selanjutnya. Tindak lanjut dari penillaian kinerja berupa reward (promosi, atau balas jasanya dinaikkan), dan punishment / sanksi.

Tabel 7. Nilai Vektor S \&V

\begin{tabular}{ccccc}
\hline No & NIK & Nama Dosen & Vector s & Vector $\mathbf{~}$ \\
\hline 1 & $21.0819 . \times x x$ & A C P & 74.56 & 0.186180504 \\
2 & $21.0819 . \times x x$ & A I S & 76.90 & 0.192034835 \\
3 & $21.0819 . x x x$ & A Y & 81.44 & 0.203361533 \\
4 & $21.0819 . x x x$ & A S R & 85.59 & 0.213744884 \\
5 & $21.0819 . \times x x$ & A M T & 81.96 & 0.204678243 \\
\hline
\end{tabular}

\section{KESIMPULAN DAN SARAN}

Kesimpulan dari hasil penelitian ini adalah: (1) Penilaian kinerja dosen bidang kompetensi belajar mengajar dapat dilakukan melalui 6 (enam) kriteria, yakni waktu, 
kerapihan, komunikasi, proses perkuliahan, penguasaan materi, dan evaluasi belajar. Langkah-langkah penilaian dengan cara: (a) Mahasiswa dibagikan form penilaian kinerja dosen, (b) Mahasiswa melakukan penilaian kinerja dosen dengan memberikan range angka penilaian 0 -100, (c) Form dikumpulkan oleh team penilai, d. Setelah di rata-rata nilai dosen, selanjutnya dianalisis dengan weighted product. (2) Penerapan metode weighted product dalam penilaian kinerja dosen, dengan sampel 5 (lima) dosen, dengan menggunakan metode weighted product dan alat (tool) excel, Hasil perhitungan diperoleh bobot yang terbaik adalah Sdr. ASR sebesar 0.213744884, sedangkan yang memiliki bobot terendah adalah Sdr. A C P sebesar 0.186180504 .

Atas dasar bobot tersebut dapat dijadikan landasan dalam pengambilan keputusan tindakan kebijakan selanjutnya. berupa reward (promosi, atau balas jasanya dinaikkan), dan punishment / sanksi. Berdasarkan uraian sebelumnya, saran untuk penelitian ini adalah membantu mengevaluasi dosen secara obyektif, sehingga membantu manajemen dalam mengambil kebijakan terhadap dosen yang bersangkutan dimasa mendatang. Penilaian dapat dikembangkan menggunakan aplikasi program (IT), terutama aplikasi penilaian yang berbasis digital dan WEB

\section{TINJAUAN PUSTAKA}

Ananta P. W. \&n Winiarti S. (2013). Sistem Pendukung Keputusan Dalam Penilaian Kinerja Pegawai Untuk Kenaikan Jabatan Pegawai Menggunakan Metode Gap Kompetensi. Jurnal Sarjana Teknik Informatika, Vol 1 No 2, 574-583

Anggraeni N. (2011) Pengaruh Kemampuan Dan Motivasi Terhadap Kinerja Pegawai. Jurnal Penelitian Pendidikan. Bandung. Vol 12 No. 2, 46-62

Dessler G. (2011). Human Resource Management, Twelfth Edition. Published by Pearson Education. Publishing as Prentice Hall. p. 435.

Hartanto H. W. (2019). Perancangan Instrumen Penilaian Kompetensi Pekerja Refinery Dan Fraksinasi Plant 3 Dan 4 PT. Smart, Tbk. Jurnal Titra, Vol. 7, No. 2, p. 31-38.

Nofriansyah D. (2015). Konsep Data Minig Vs Sistem Pendukung Keputusan. Yogyakarta: Deepublish. p. 47-48

Permanasari R., Setyaningrum. R.M., \& Sundari.S, (2014) Model Hubungan Kompetensi, Profesionalisme Dan Kinerja Dosen. Jurnal Bisnis Manajemen \& Perbankan Vol. 1 No. 2. $157-174$

Presiden Republik Indonesia (2009). Peraturan Pemerintah Republik Indonesia Nomor 37 Tahun 2009, Tentang Dosen, Jakarta Kementerian Sekretariat Republik Indonesia

Presiden Republik Indonesia (2005). Undang-Undang Republik Indonesia Nomor 14 Tahun 2005, Tentang Guru dan Dosen. Jakarta. Kementerian Sekretariat Republik Indonesia

Presiden Republik Indonesia .(2005). Undang-Undang Republik Indonesia Nomor 20 Tahun 2003 Tentang Sistem Pendidikan Nasional. Jakarta. Kementerian Sekretariat Republik Indonesia

Sari, R., \& Susilo, H. (2018). Pengaruh Kepuasan Kerja Terhadap Kinerja Karyawan Dengan Organizational Citizenship Behavior Sebagai Variabel Intervening. Jurnal Administrasi Bisnis (Jab) , Vol. 64 No. 1, 28-35 
Siregar M. J. (2018). Rancangan Model Penilaian Kinerja Karyawan Dengan Metode 360 degree Di Departemen WareHouse. Profiesiensi , Vol 6 No. 1, 33-40.

Taufiq R. (2015). Penilaian Kinerja Dosen Dalam Bidang Belajar Mengajar Di Fakultas Teknik Universitas Muhammadiyah Tangerang. Faktor Exacta, Vol. 5 No. 1: 77-85.

Yuningsih. E \& Ardianti (2019). Pengaruh Kompetensi Dan Motivasi Terhadap Kinerja Pegawai. Jurnal Visionida, Vol 5 No1. 32-45 